\title{
COVID 19: Resveratrol as a Potential Supplement to Mitigate the Cardiotoxicity Associated with Chloroquine and Hydroxychloroquine Treatment
}

\author{
Rotimi Damilare Emmanuel $^{1}$ (D), Afolabi Boluwatife Lawrence 1,* ${ }^{(D)}$, Adeyemi Stephen Oluyomi ${ }^{1(D)}$ \\ 1 Department of Biochemistry, Landmark University, Omu-Aran - 251101, Nigeria; rotimi.damilare @ lmu.edu.ng (D.R.E.); \\ bolu.afolabi@gmail.com (A.B.L.); yomibowa@yahoo.com (A.S.O.); \\ * Correspondence:bolu.afolabi@gmail.com;
}

Received: 5.11.2020; Revised: 4.12.2020; Accepted: 6.12.2020; Published: 9.12.2020

\begin{abstract}
The challenges of SARS-CoV-2 have frightened the world due to a lack of effective treatment. Many clinicians have adopted drug repositioning because of the urgent need to contain the viral pandemic. Several studies have demonstrated the in vitro and in vivo antiviral efficacy of chloroquine and hydroxychloroquine in the treatment of SARS-CoV-2. However, the cardiovascular toxicity of chloroquine and hydroxychloroquine stand as a limitation to their general use to treat SARSCoV-2. Thus, it is necessitated the search for an adjuvant that could be used alongside these treatments to mitigate the undesired effect. The cardioprotective activity of resveratrol could serve to mitigate the cardiovascular toxicity of chloroquine and hydroxychloroquine. Its antioxidant and anti-inflammatory properties synergistically with chloroquine or hydroxychloroquine could also mitigate the antiviral activity of SARS-CoV-2. In this review, we explore chloroquine and hydroxychloroquine for SARS$\mathrm{CoV}-2$ treatment and suggest their synergetic use with resveratrol as a recommended therapy to mitigate cardiovascular toxicity and contribute to their antiviral effects.
\end{abstract}

Keywords: natural products; drug repurposing; treatment strategies; Covid-19; antiviral; toxicity.

(C) 2020 by the authors. This article is an open-access article distributed under the terms and conditions of the Creative Commons Attribution (CC BY) license (https://creativecommons.org/licenses/by/4.0/).

\section{Introduction}

Severe acute respiratory syndrome coronavirus 2 (SARS-CoV-2) is an important human and animal viral infection that has frightened the world due to a lack of effective treatment [1]. It can cross species barriers with newly emerged properties, causing novel and fatal diseases [2]. Lack of effective therapy against SARS-CoV-2 has led clinicians to drug repositioning using existing antiviral and antimalarial drugs to limit the severity and treat SARS-CoV-2 [3]. The antimalarial drug, chloroquine, and analog hydroxychloroquine have been proven to exhibit antiviral properties and effectively treat autoimmune diseases. However, these drugs can have cardiovascular adverse effects and decrease nasopharyngeal viral load, which could be an exposure mechanism to ventricular arrhythmias [4]. On the other side, resveratrol and its analogs have shown antiviral effects against respiratory infections [6] and possess cardioprotective effects, which are enhanced by its antioxidant and anti-inflammatory activities. Although clinical evidence to support this is minimal, there is contrasting evidence pointing to their potential safety [5]. However, there is an urgent demand to produce effective therapy for SARS-CoV-2 treatment. Drug repositioning with a known safety profile and side effects might be effective. This review aims to explore the use of chloroquine and 
hydroxychloroquine with resveratrol to mitigate the adverse cardiotoxicity induced by chloroquine and hydroxychloroquine and recommend it as a treatment measure for SARSCoV-2 with supporting data of in vitro, in vivo, and clinical trials.

\section{Chloroquine and Hydroxychloroquine}

Chloroquine and its analog, hydroxychloroquine, are widely available old drugs used in treating malaria and autoimmune diseases $[1,7]$. However, its excellent anti-inflammatory and immunoregulatory properties are quite surprising to medical experts. Both compounds can inhibit proteolytic processes, acidification of endosomal cells, and glycosylation of host receptors, thereby blocking the viral entry into the cells [8]. They also inhibit lysosomal activities, autophagy, and the synthesis of pro-inflammatory cytokines like tumor necrosis factor- $\alpha$ (TNF- $\alpha$ ), interleukin-6 (IL-6), and interferon- $\gamma$ (IFN- $\gamma$ ) in the host cells [9]. The replication of SARS-CoVs in cells results in pulmonary endothelial and epithelial cells' injury, causing an inflammatory increase of cytokines in the plasma. The anti-inflammatory and immunoregulatory property chloroquine and hydroxychloroquine pose labeled them as a "game-changer" with the possibility of attenuating the inflammatory response and replication of SARS-CoVs [8]. Chloroquine and hydroxychloroquine mediated inhibition of SARS-CoVs by inhibiting pro-inflammatory cytokines and markers using in vitro studies of peripheral blood mononuclear cells has been well established [8]. In vivo study, using mice has demonstrated that these compounds have some activity against the human SARS-CoV virus [8]. A clinical trial was carried out on hydroxychloroquine by Gautret, and his coworkers show a reduction/clearance in the viral load of SARS-CoV-2 patients. However, it has a limitation of the small sample size [10]. These compounds have shown in vitro activities against several viruses [1]; however, the results obtained against the SARS-CoV-2 virus were more promising compared to other viral disease trials [8]. A great limitation to some of the evidence is that there is no high-quality way to ascertain the efficacy of these compounds in treating viral infection.

\section{Mechanism of Action Against Viral Infections}

The mechanisms of action of hydroxychloroquine and chloroquine are closely related because hydroxychloroquine is an analog of chloroquine. The mechanism of action is not clearly understood as many studies have revealed different mechanisms. Both compounds can prevent viral entry in the cell and also stop post-entry events [8]. Chloroquine stops viral entry by inhibiting the enzyme quinone reductase II, an enzyme required to synthesize sialic acid in the body [11]. During viral capsid injection into the cell, sialic acid is important for the viral attachment to the cell [12]. Studies have also shown that chloroquine and hydroxychloroquine interfere with angiotensin-converting enzyme 2 receptor (ACE2) glycosylation by preventing the virus from entering the cells $[13,14]$. SARS-CoV-2 has also been proven to use this mechanism for its replication in the cell. It also fuses with the endosomal membrane in an acidic medium in the lysosome, thereby uncoating itself and releasing its content into the cell [15]. Chloroquine can increase the $\mathrm{pH}$ of endosomes and therefore interfere with virus replication in its early stage. Hydroxychloroquine also increases endosomal $\mathrm{pH}$ and interfere with toll-like-receptor signaling important in the transcription of pro-inflammatory genes [14]. Chloroquine hinders the degradation of lysosomal protein and its fusion with autophagosomes $[16,17]$. In vitro studies also prove that chloroquine is anti-autophagy via its cytotoxic effect 
on cells [18]. It also interferes with proteolytic processes via the impairment of posttranslational modification of viral protein [19]. Both compounds are anti-inflammatory agents; they reduce tumor necrosis factor (TNF $\alpha$ ) released during trauma and infection [20]. Hydroxychloroquine inhibits T-cells activation and the expression of CD145 via hindering the major histocompatibility complex (MCH) class II expression [21,22]. Both drugs' ability to work via a multi-target mechanism raised the interest of using them to treat SARS-CoV-2.

\section{Chloroquine and Hydroxychloroquine Versus SARS-CoV-2 (In vitro)}

In vitro studies have shown antiviral chloroquine and hydroxychloroquine activities before the onset of 2019 SARS-Cov-2 [8]. Both compounds inhibit a diverse range of CoVs and non CoVs virus replication [2]. However, the table below summarizes the activities of chloroquine and hydroxychloroquine versus SARS-CoV-2 in vitro.

Table 1. In vitro activity of chloroquine and hydroxychloroquine against SARS-CoV-2.

\begin{tabular}{|c|c|c|c|c|}
\hline Drug & Experimental Design & Experimental Outcome & $\begin{array}{l}\mathbf{E C}_{50} \\
(\mu \mathrm{M})\end{array}$ & Reference \\
\hline Chloroquine & $\begin{array}{l}\text { Infected Vero E6 cell culture } \\
\text { with SARS-CoV-2 at } \\
\text { Multiplicity of infection (MOI) } \\
\text { of } 0.05 \text { and treated with a } \\
\text { varying dosage of the drug }\end{array}$ & $\begin{array}{l}\text { Reduction in viral replication. } \\
\text { Highly effective, especially when } \\
\text { combined with Remdesivir to treat } \\
\text { SARS-CoV-2 }\end{array}$ & 1.13 & {$[23]$} \\
\hline Chloroquine & $\begin{array}{l}\text { Vero E6 cells infected with } \\
\text { SARS-CoV-2 (MOI of } 0.01 \text { ) } \\
\text { and treated at varying dosage of } \\
0.032,0.16,0.80,4,20,100 \mu \mathrm{M} \\
\text { for } 24 \text { or } 48 \text { hours }\end{array}$ & $\begin{array}{l}\text { Reduction in the replication of the } \\
\text { virus } \\
\text { With an EC50 value of } 5.47 \mu \mathrm{M} \\
\text { after } 48 \mathrm{~h} \text { of incubation }\end{array}$ & 5.47 & {$[24]$} \\
\hline Chloroquine & $\begin{array}{l}\text { Infected Vero E6 cell culture } \\
\text { with SARS-CoV-2 at varying } \\
\text { MOIs of } 0.01,0.02,0.2 \text {, and } 0.8 \\
\text { at a varying dosage of } 2.71 \text {, } \\
3.81,7.14 \text {, and } 7.36 \mu \mathrm{M}\end{array}$ & Reduction in viral replication & $2.71-7.36$ & [4] \\
\hline Hydroxychloroquine & $\begin{array}{l}\text { Vero E6 cells were infected } \\
\text { with SARS-CoV-2 at MOI of } \\
0.01 \text { and treated at varying } \\
\text { dosage of } 0.032,0.16,0.80,4 \text {, } \\
20,100 \mu \mathrm{M} \text { for } 24 \text { or } 48 \text { hours }\end{array}$ & Reduction in viral replication & 0.72 & [24] \\
\hline Hydroxychloroquine & $\begin{array}{l}\text { SARS-CoV-2 infected Vero E6 } \\
\text { cell culture at varying dosage of } \\
(4.51,4.06,17.31 \text {, and } 12.96 \\
\mu \mathrm{M}\end{array}$ & Reduction in viral replication & $\begin{array}{l}4.06- \\
17.31\end{array}$ & [4] \\
\hline
\end{tabular}

An experiment carried out by Wang and his coworkers using infected Vero E6 cells with SARS-CoV-2 multiplicity of infections (MOIs) 0.05 showed that chloroquine could inhibit the viral replication and was more effective when combined with remdesivir [23]. Also, chloroquine and hydroxychloroquine at varying dosage reduce viral replication with an EC50 of $5.47 \mu \mathrm{M}$ and $0.72 \mu \mathrm{M}$, respectively. In the experiment carried out by Yao and his coworkers, hydroxychloroquine was more effective than chloroquine against SARS-CoV-2 [24]. The MOI of SARS-Cov-2 was varied by Liu and his coworkers with a varying dosage of chloroquine and hydroxychloroquine to treat the infected cells. Both drugs were active against SARS-CoV2 by reducing viral replication; however, in contrast to the experiment carried out by Wang and coworkers, chloroquine was more effective than hydroxychloroquine, having an EC50 between $2.71 \mu \mathrm{M}$ and $7.36 \mu \mathrm{M}$ [4]. The interpretation of these findings is that chloroquine and its analog hydroxychloroquine are capable of attenuating SARS-CoV-2 in vitro. 


\section{In vivo Activities of Chloroquine Against SARS-CoVs}

The data available for the in vivo antiviral activities of chloroquine against the SARSCoVs viruses are limited. There is no reported data on in vivo study of hydroxychloroquine against SARS-CoVs. The present study showed no significant chloroquine activities against SARS-CoVs; however, it significantly reduced HCoV-OC43 replication in mice [25] and increased the fetus survival rate of infected mice [26].

Table 2. In vivo activity of Chloroquine against SARS-CoV-2.

\begin{tabular}{|c|c|c|c|c|}
\hline Drug & $\begin{array}{l}\text { Experimental } \\
\text { Design }\end{array}$ & Dosage & $\begin{array}{l}\text { Experimental } \\
\text { Outcome }\end{array}$ & Reference \\
\hline Chloroquine & $\begin{array}{l}\text { Intraperitoneal or } \\
\text { intranasal } \\
\text { administration of } \\
\text { SARS-CoV in mice }\end{array}$ & $1-50 \mathrm{mg} / \mathrm{d}$ & $\begin{array}{ll}\text { Tolerated } & \text { but } \\
\text { ineffective } & \end{array}$ & [27] \\
\hline Chloroquine & $\begin{array}{l}\text { Subcutaneous } \\
\text { administration of } \\
\text { HCoV-OC43 in mice }\end{array}$ & $15 \mathrm{mg} / \mathrm{d}$ & Effective & [25] \\
\hline Chloroquine & $\begin{array}{l}\text { Subcutaneous } \\
\text { administration of } \\
\text { HCoV-OC43 in mice }\end{array}$ & $30 \mathrm{mg} / \mathrm{d}$ then $15 \mathrm{mg} / \mathrm{d}$ & effective & [26] \\
\hline Chloroquine & $\begin{array}{l}\text { Subcutaneous } \\
\text { administration } \\
\text { FIPV in cat }\end{array}$ & $10 \mathrm{mg} / 3$ days & No significant effect & [28] \\
\hline
\end{tabular}

\section{Chloroquine and Hydroxychloroquine Versus SARS-CoV-2: Clinical Trials}

Available clinical trials to understand the effectiveness of chloroquine and hydroxychloroquine treatment against SARS-CoV-2 infected patients are very limited (Table 3). Some evidence has shown a significant benefit of using chloroquine and hydroxychloroquine in SARS-CoV-2 treatment; however, it must be stated that these shreds of evidence have significant limitations like small sample size and appropriate statistical presentation, which cannot be overlooked.

Table 3. In vivo clinical trials of Chloroquine and hydroxychloroquine against SARS-CoV-2.

\begin{tabular}{|c|c|c|c|c|c|}
\hline Drug & $\begin{array}{l}\text { Experimental } \\
\text { Design }\end{array}$ & Dosage & $\begin{array}{l}\text { Reported } \\
\text { Severity of } \\
\text { Infection }\end{array}$ & $\begin{array}{l}\text { Experimental } \\
\text { Outcome }\end{array}$ & Reference \\
\hline Hydroxychloroquine & $\begin{array}{l}\text { Uncontrolled } \\
\text { noncomparative } \\
\text { open-label } \\
\text { observational study } \\
\text { on } 80 \text { patients }\end{array}$ & $\begin{array}{l}200 \mathrm{mg} \text { of } \mathrm{HCQ} \\
\text { trice daily for } \\
\text { 10days }+500 \mathrm{mg} \\
\mathrm{AZ} \text { on day } 1 \\
\text { followed by } \\
250 \mathrm{mg} / \text { day from } \\
\text { the } 4^{\text {th }} \text { day }\end{array}$ & Mild illness & $\begin{array}{l}\text { Clinical improvement } \\
\text { with reduction in } \\
\text { nasopharyngeal viral } \\
\text { load. } 83 \% \text { of the } \\
\text { patients had a negative } \\
\text { viral culture at the end } \\
\text { of the } 7^{\text {th }} \text { day. }\end{array}$ & {$[10]$} \\
\hline Hydroxychloroquine & $\begin{array}{lr}\text { Open } & \text { labeled } \\
\text { randomize parallel- } \\
\text { group trial on } 62 \\
\text { patients }\end{array}$ & $\begin{array}{l}200 \mathrm{mg} \text { of } \mathrm{HCQ} \\
\text { twice daily }\end{array}$ & $\begin{array}{l}\text { Moderate } \\
\text { illness }\end{array}$ & 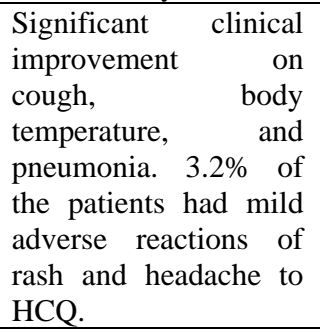 & [29] \\
\hline Hydroxychloroquine & $\begin{array}{l}\text { Controlled } \\
\text { randomized open- } \\
\text { label trial on } 30 \\
\text { patients }\end{array}$ & $\begin{array}{l}\text { 200mg of HCQ } \\
\text { twice daily }\end{array}$ & Mild illness & $\begin{array}{lr}\text { No } & \text { statistically } \\
\text { significant difference } \\
\text { in clinical outcomes } \\
\text { between the two } \\
\text { groups }\end{array}$ & [30] \\
\hline Hydroxychloroquine & $\begin{array}{l}\text { Uncontrolled } \\
\text { noncomparative } \\
\text { open-label }\end{array}$ & $\begin{array}{l}\text { 600mg of } \mathrm{HCQ} \\
\text { per day for } \\
\text { 10days }+500 \mathrm{mg}\end{array}$ & $\begin{array}{l}\text { Moderate } \\
\text { illness }\end{array}$ & $\begin{array}{l}80 \% \text { of the patient had } \\
\text { positive SARS-CoV-2 } \\
\text { in their RNA at day } 5 \&\end{array}$ & [31] \\
\hline
\end{tabular}




\begin{tabular}{|c|c|c|c|c|c|}
\hline Drug & $\begin{array}{l}\text { Experimental } \\
\text { Design }\end{array}$ & Dosage & $\begin{array}{l}\text { Reported } \\
\text { Severity of } \\
\text { Infection }\end{array}$ & $\begin{array}{l}\text { Experimental } \\
\text { Outcome }\end{array}$ & Reference \\
\hline & $\begin{array}{l}\text { observational study } \\
\text { on } 11 \text { patients }\end{array}$ & $\begin{array}{l}\text { AZ on day } 1 \\
\text { followed } r \text { by } \\
250 \mathrm{mg} / \text { day from } \\
\text { day } 2-5\end{array}$ & & $\begin{array}{l}6 \text { after treatment } \\
\text { initiation }\end{array}$ & \\
\hline Hydroxychloroquine & $\begin{array}{l}\text { A longitudinal cohort } \\
\text { study on } 807 \text { patients }\end{array}$ & $\begin{array}{l}\text { Dosages not } \\
\text { available }\end{array}$ & $\begin{array}{l}\text { Moderate } \\
\text { illness }\end{array}$ & $\begin{array}{l}\text { No reduction in } \\
\text { mortality rate or need } \\
\text { for mechanical } \\
\text { ventilation in groups } \\
\text { with HCQ treatment. }\end{array}$ & [32] \\
\hline Hydroxychloroquine & $\begin{array}{l}\text { A longitudinal cohort } \\
\text { study on } 181 \text { patients }\end{array}$ & $\begin{array}{lr}600 \mathrm{mg} \text { of } & \text { HCQ } \\
\text { per day } & \text { for } \\
48 \text { hours } & \text { after } \\
\text { admission } & \end{array}$ & $\begin{array}{l}\text { Moderate } \\
\text { illness }\end{array}$ & $\begin{array}{l}\text { No reduction in the } \\
\text { number of deaths and } \\
\text { acute respiratory } \\
\text { distress syndrome } \\
\text { within } 7 \text { days. }\end{array}$ & {$[33]$} \\
\hline Hydroxychloroquine & $\begin{array}{l}\text { Uncontrolled } \\
\text { noncomparative } \\
\text { observational study } \\
\text { on } 1061 \text { patients }\end{array}$ & $\begin{array}{l}200 \mathrm{mg} \text { of } \mathrm{HCQ} \\
\text { trice daily for } \\
10 \text { days }+500 \mathrm{mg} \\
\text { AZ on day } 1 \\
\text { followed by } \\
250 \mathrm{mg} / \text { day from } \\
\text { the } 4^{\text {th }} \text { day }\end{array}$ & Mild illness & \begin{tabular}{lr}
\multicolumn{3}{l}{ Significant reduction in } \\
mortality rate \\
compared with patients \\
under different \\
regiments from other \\
hospitals.
\end{tabular} & [34] \\
\hline Hydroxychloroquine & $\begin{array}{l}\text { A longitudinal cohort } \\
\text { study on } 63 \text { patients }\end{array}$ & $\begin{array}{l}\text { Dosages not } \\
\text { available }\end{array}$ & $\begin{array}{l}\text { Moderate } \\
\text { illness }\end{array}$ & $\begin{array}{l}\text { Significant } \\
\text { improvement in } \\
\text { respiratory status with } \\
\text { no significant } \\
\text { difference in the } \\
\text { mortality rate, } \\
\text { therefore no significant } \\
\text { clinical efficacy. }\end{array}$ & [35] \\
\hline Hydroxychloroquine & $\begin{array}{l}\text { Randomized open- } \\
\text { label control study on } \\
150 \text { patients }\end{array}$ & $\begin{array}{l}1200 \mathrm{mg} \text { of HCQ } \\
\text { per day for } 3 \text { days } \\
\text { followed by } \\
300 \mathrm{mg} \text { per day for } \\
2 \text { weeks in mild- } \\
\text { moderate patients } \\
\text { or } 3 \text { weeks in } \\
\text { severe patients }\end{array}$ & $\begin{array}{l}\text { Mild- } \\
\text { moderate } \\
\text { illness }\end{array}$ & $\begin{array}{l}\text { No significant higher } \\
\text { negative conversion } \\
\text { was observed. Adverse } \\
\text { drug reaction was } \\
\text { observed in two of the } \\
\text { patients. }\end{array}$ & [36] \\
\hline Chloroquine & $\begin{array}{l}\text { Randomized double- } \\
\text { blinded safety- } \\
\text { oriented study on } 81 \\
\text { patients }\end{array}$ & $\begin{array}{l}\text { High dose: } \\
600 \mathrm{mg} \text { twice } \\
\text { daily for } 10 \text { days } \\
\text { Low dose: } 450 \mathrm{mg} \\
\text { twice on day } 1 \\
\text { and once daily for } \\
4 \text { days }\end{array}$ & $\begin{array}{l}\text { Moderate } \\
\text { illness }\end{array}$ & $\begin{array}{l}50 \% \text { reduction in } \\
\text { lethality as compared } \\
\text { to a low dose group; } \\
\text { therefore high dosage } \\
\text { is not recommended } \\
\text { for use. No significant } \\
\text { difference in clinical } \\
\text { improvement. }\end{array}$ & [37] \\
\hline Hydroxychloroquine & $\begin{array}{lr}\text { Safety } & \text { oriented } \\
\text { longitudinal } & \text { cohort } \\
\text { study on } 84 \text { patients }\end{array}$ & $\begin{array}{ll}\begin{array}{l}\text { Dosage } \\
\text { available }\end{array} & \text { not }\end{array}$ & $\begin{array}{l}\text { Moderate- } \\
\text { severe illness }\end{array}$ & $\begin{array}{l}\text { It shows an increase in } \\
\text { QT interval } \\
\text { prolongation, drug- } \\
\text { induced torsades de } \\
\text { pointes (TdP), and } \\
\text { drug-induced-sudden } \\
\text { cardiac death (SCD). }\end{array}$ & {$[38]$} \\
\hline Hydroxychloroquine & $\begin{array}{l}\text { Non-randomized } \\
\text { open-label study on } \\
36 \text { patients }\end{array}$ & $\begin{array}{l}600 \mathrm{mg} \text { per day for } \\
10 \text { days }\end{array}$ & $\begin{array}{l}\text { Moderate } \\
\text { illness }\end{array}$ & $\begin{array}{l}\text { There was a significant } \\
\text { reduction in the viral } \\
\text { load of patients } \\
\text { receiving HCQ only at } \\
\text { day } 6 \text { and negative } \\
\text { SARS-CoV-2 test in all } \\
\text { six patients that } \\
\text { received a combination } \\
\text { of HCQ and AZT. }\end{array}$ & {$[10]$} \\
\hline Chloroquine & $\begin{array}{lr}\text { Interim study on } & 100 \\
\text { patients from } & 10 \\
\text { hospitals } & \end{array}$ & Not reported & Not applicable & $\begin{array}{l}\text { Chloroquine more } \\
\text { superior to control in } \\
\text { promoting a virus- } \\
\text { negative conversion } \\
\text { and shortening the }\end{array}$ & [39] \\
\hline
\end{tabular}




\begin{tabular}{l|l|l|l|l|l}
\hline Drug & $\begin{array}{l}\text { Experimental } \\
\text { Design }\end{array}$ & Dosage & $\begin{array}{l}\text { Reported } \\
\text { Severity of } \\
\text { Infection }\end{array}$ & $\begin{array}{l}\text { Experimental } \\
\text { Outcome }\end{array}$ & Reference \\
\hline & & $\begin{array}{l}\text { disease course with no } \\
\text { adverse effect. }\end{array}$ &
\end{tabular}

An experiment carried out by Gautret, and his coworkers showed that $600 \mathrm{mg}$ of hydroxychloroquine for ten days lessen the viral load of the patient who received the medication. The combined use of hydroxychloroquine with azithromycin completely cleared SARS-CoV-2 in all six patients that received the medication [10]. Gautret et al. [10] also carried out another experiment on 80 hospitalized using the combination of hydroxychloroquine and azithromycin, $83 \%$ had an undetectable viral load on day seven, and $81 \%$ of the patients survived to hospital discharge [10]. Molina et al. also carried out a longitudinal cohort study on 11 patients using the same dosage as Gautret et al.. The result shows that $80 \%$ still had SARS-CoV-2 RNA in their nasopharyngeal swap, which is in contrast to Gautret et al. observation [40]. Chen et al. experiment on 62 patients using 200mg of hydroxychloroquine twice daily showed significant clinical improvement on cough, body temperature, and pneumonia; however, 2 of the patients had an adverse reaction of rash and headache [29]. Million et al.'s experiment showed that there is a significant mortality reduction in 1061 SARS-CoV-2 patients using a combination of hydroxychloroquine and azithromycin [34]. Borba et al. compared a high dosage of chloroquine $(600 \mathrm{mg})$ with a low dosage $(450 \mathrm{mg})$ on 81 patients and found out 50\% reduction in lethality as compared with a low dosage; however, no significant clinical difference between both dosages [37]. Gao et al. carried out an interim report on 100 patients. They stated that chloroquine is more superior to control in promoting a virus-negative conversion and shortening the disease course with no adverse effect [39]. Some other experiments carried out on hydroxychloroquine also showed no significant improvement in SARS-CoV-2 patients [29,33,36].

These reports have a common limitation of small sample size, many are not a peeredreviewed article. They have reported different outcomes using the same drug and similar dosage (inconsistency in their results), and therefore these reports should be treated as a sole hypothesis.

\section{Contraindication and Adverse Effect of Chloroquine and Hydroxychloroquine}

The possible efficacy of chloroquine and its analog hydroxychloroquine as a therapy against SARS-CoV-2 has been proven to be associated with adverse cardiovascular toxicity $[23,39,40]$. These drugs' cardiovascular effect involves cardiac arrhythmias, changes in the electrical conductivity of the myocardium [41-43], and myocardial hypertrophy, a structural change in the entire myocardium. The fundamental mechanism of chloroquine and hydroxychloroquine in cardiovascular toxicity is autophagy inhibition [44,45], which is antiarrhythmic or proarrhythmic depending on the elementary condition [46,47].

The common hypersensitivity to chloroquine and hydroxychloroquine is abdominal discomfort and nausea [48]. Retinal field changes might occur due to the binding of the drugs to melanin, damaging the cornea and retina [49]. According to some reports, hydroxychloroquine has been safer and less toxic than chloroquine; however, this lacks substantial evidence [20]. The chances of experiencing some of these side effects are low in adults except in elderly patients [2]. A report showed that side effects would only be seen if the drug is continually used for 5 years at a dosage of $6.5 \mathrm{mg} / \mathrm{kg} / \mathrm{d}$ [50]. Co-administration of chloroquine and hydroxychloroquine with other drugs might also increase the risk of its side 
effect. The combined use of hydroxychloroquine and azithromycin might prolong the QTc interval, according to Gautret et al. [10]. There are few cases of both drugs causing a lifethreatening disease, cardiomyopathy, since both drugs can prolong QTc [51,52]. Other toxicities associated with hydroxychloroquine that is less reported include ototoxicity and urticarial [53].

The cell's inability to degrade and recirculate the heart's cellular components results in accelerated cell damage and ischemia-reperfusion injury, causing a change in autophagic flux and aggravated cell death mechanism [54-56]. The inhibition of different ion channels plays an opposite and different role in myocardial death. The blockage of $\mathrm{Na}^{+}$and $\mathrm{K}^{+}$might be responsible for intraventricular blockage with multiple bundle branches and prolonged action potential time, respectively. In contrast, the cell exhibits a protective mechanism by inhibiting $\mathrm{Na}^{+}$and $\mathrm{Ca}^{2+}$ load to oppose myocardial death [57]. The contrasting balanced activity of various ion channels might be responsible for limited prolonged QT interval in low and moderate dosage for a short time. Chloroquine affects the QRS complex's dilation and causes arrhythmia in the cardiac muscles when it binds to $\mathrm{Na}^{+}, \mathrm{K}^{+}$, and $\mathrm{Ca}^{2+}$ ions. These drugs' effect is dose-dependent [58]; the rhythmic changes in the heart are reversible when the drug is withdrawn.

Cardiomyopathy, however, is irreversible, but the treatment must have been for months before the onset of its effect. Some essential questions need an urgent answer when considering chloroquine and hydroxychloroquine as SARS-CoV-2 treatment due to their cardiac toxicity and the possibility of eliciting different mechanisms of toxicity. How to proceed with the usage of these drugs in the treatment of SARS-CoV-2? Is it wise to synergistically combine them with other potential drugs knowing that its cardiovascular toxicity mechanism depends on the underlying elementary condition? How can we supplement the drug to reduce the cardiotoxicity effect? Available reports show that the data available on randomized clinical trials are not significant enough to prove the effective dosage of the drugs and their time of use in the treatment of SARS-CoV-2. These quinolones' potential clinical benefit is significant to their toxicity because cardiac toxicity starts developing after the prolonged use of the drug at a high dose. Adverse drug reactions and prolonged QT intervals in some patients might be due to a good underlying ailment like diabetic patients and patients with electrolyte disorders. A baseline electrocardiogram should be checked on patients and their possible exclusion before the onset of the trial. Since the potential benefit of chloroquine and hydroxychloroquine supersedes its mild and tolerable side effect, it will be wise and thoughtful not to jeopardize a patient's life and consider these drugs to treat SARS-CoV-2, putting in mind the important questions for a better clinical outcome [59].

\section{Resveratrol as a Potential Supplement with Chloroquine and Hydroxychloroquine}

The use of natural products has been widely accepted throughout the history of disease prevention and treatment. Among such products available is resveratrol, which has been noted to play a major role in disease treatment via its potent defensive antioxidant. Resveratrol $\left(3,4^{\prime}, 5\right.$ - trihydroxystilbene) from the stilbene family (phenolic compounds) with two benzene rings linked via isopropyl moiety. Cis- and trans- forms ( $\mathrm{Z}$ and $\mathrm{E})$ stereoisomers of resveratrol exist. The E form has been implicated for the antioxidant and anticancer potential of the product. Resveratrol is a naturally occurring phytoalexin that was initially isolated in Veratrum grandiflorum in 1940. Resveratrol is well distributed in plant families such as Vitaceae, 
Leguminosae, Cyperaceae, Gnetaceae, Dipterocarpaceae, and other food products, including grapes and blue, peanuts, cranberry juice, wine, cranberries, and mulberries. Under acidic conditions, it is poorly soluble in water [60].

Reports have shown that resveratrol has poor bioavailability and rapid metabolism, limiting its use as a drug. To improve its therapeutic effects, there will be increased oral dose administration [61]. Resveratrol intake in humans has shown to be a well-tolerated compound. However, at a concentration of more than $1 \mathrm{~g} / \mathrm{Kg}$, it produces side effects such as diarrhea, abdominal pain, and nausea [62].

Different effects of resveratrol include cardioprotective, antioxidant, anti-microbial, and anticancer properties [63]. However, several studies have attributed the antioxidant and anti-inflammatory properties of resveratrol about its cardioprotective activities [64-66]. Clinical trials of resveratrol administration $(20 \mathrm{mg} /$ day and $350 \mathrm{mg} /$ day for 2 months and 6 months, respectively) significantly improved the inflammatory state in patients with high cardiovascular risk or diseases [67].

However, in vitro resveratrol studies revealed several cardioprotective properties due to its multiple molecular targets interaction [65,68]. Resveratrol restores ROS/antioxidant balance and counters the damages induced by oxidative stress, hence reveal its antioxidant properties [69]. Meng et al. [70] revealed that resveratrol also attenuates the inflammatory response and contributes to its cardioprotective effects. Schwager et al. [71] revealed that at 6.25-50 $\mu \mathrm{M}$, resveratrol modulated the immune and endothelial cells to protect against inflammation via cytokine and chemokine profiles. For example, resveratrol suppressed NF$\kappa \mathrm{B}$ and upregulated sirtuin-1 [72].

The anticancer activity of resveratrol potentially protects against the initiation and progression of the tumor [70]. In different human tumor cell lines, resveratrol's anticancer activity was attributed mostly to apoptosis induction through the direct caspase cascade activation of anti-apoptotic pathways inhibition [73].

Resveratrol was noted as an antifungal and antibacterial agent. Resveratrol had shown to inhibit Gram-positive pathogens and Gram-negative pathogens at MIC 100-200 $\mu \mathrm{g} / \mathrm{ml}$ and MIC greater than $200 \mu \mathrm{g} / \mathrm{ml}$, respectively [63]. Euba et alet al. [74] revealed that $150 \mathrm{mg} / \mathrm{kg}$ resveratrol administered orally decreased the bacterial burden significantly in lung tissue with respiratory infection of Haemophilus influenza.

Presently, SARS-CoV-2, emerging respiratory viruses, have no drug to prevent or treat it. Hence, alternative potential treatment options are being explored to enhance disease management due to the scarce antiviral therapies and the disease's pathological complexity. A natural compound such as resveratrol should have been considered due to its therapeutic potential in several respiratory viral infections. Resveratrol and its analogs have been reported to show antiviral effects against respiratory infections such as influenza viruses, respiratory syncytial virus, coronavirus, metapneumovirus, and rhinovirus by directly inhibiting the viral replication and/or host immune response modulation [6]. The antioxidant, anti-inflammatory properties, and underlying cardioprotective resveratrol activities could help manage the various symptoms associated with respiratory virus disease, especially coronavirus.

Although with the low solubility and fast metabolism, its use in clinical practices might require a higher dose in humans with potential side effects such as DNA damage, lipid peroxidation, and cell death [62]. Hence, some areas to consider include the dose to use for its health benefits with no side effects. Different studies showing the antiviral activity of resveratrol in vivo at different doses and treatment days all observed decreased viral load. 
For some decades, coronaviruses have shown to be a pathogen found in humans, though not much recognition was given until the outbreak of MERS-CoV (Middle East Respiratory Syndrome Coronavirus) and SARS-CoV (Severe Acute Respiratory Syndrome Coronavirus) and also SARS-Cov-2 [75,76]. MERS-CoV and SARS-CoV have been traced to have originated from animal contact [76]. Phylogenetic analyses have shown that SARS-like coronaviruses found in bat was closely linked to SARS-Cov-2, and has about $79 \%$ similarity with SARS-CoV and 50\% similarity with MERS-CoV [76].

Zhao et al. [77] revealed that in both in vivo and in vitro studies, resveratrol administration exhibited antiviral activities against different viral pathogens [77]. Resveratrol also significantly inhibited the in vitro replication of MERS-CoV by inhibiting the production of RNA and other pleiotropic effects [78]. Zhao et al. [79] showed inhibition of viral replication and death rate by resveratrol in ducklings infected with duck enteritis virus. Resveratrol was able to suppress the pseudorabies virus in vitro by inhibiting intracellular viral multiplication [80]. Different doses of resveratrol supplementation in piglets inoculated with pseudorabies virus for seven days before infection significantly reduced the viral loads compared to the untreated group and high survival rates [79]. Although resveratrol had low bioavailability, the use of nanoparticle formulations may improve stability and absorption [81,82]. Presently, no data have used resveratrol in the treatment of SARS-CoV-2; however, available studies showed that it might be an adjunctive antiviral agent to consider.

\section{Cardioprotective Activity of Resveratrol}

Cardioprotective activity is the mechanism of action that aids heart protection by reducing or preventing myocardial damage. Bohm et al. [83] revealed that resveratrol decreases the death rate related to coronary heart disease. Due to its antioxidant activities, resveratrol increases vasodilation, decreases aggregation of platelet, suppresses low-density lipoprotein oxidation, and promotes the activity of endothelial nitric oxide synthase, thereby suppressing atherosclerotic changes and ultimately enhancing the cardioprotective effect. Four weeks of resveratrol injection $(1 \mathrm{mg} / \mathrm{kg} /$ day i.p.) in Sprague Dawley rats effectively suppressed the infarct size, which shows a potent cardioprotective effect. The echocardiographic analysis showed significantly improved left ventricle systolic and diastolic function. Expression of TGF-b1 mRNA and atrial natriuretic peptide level was analyzed with a quantitative PCR method, which was higher in the untreated groups than those treated with resveratrol [84]. Another possible mechanism for the cardioprotective activity in human cardiac cells could be as a result of the increase in the NF-kB activity [85]. In hypertensive rats, resveratrol protected both the cardiac and vascular tissues by decreasing ROS accumulation, thereby revealing its potential to increase its therapeutic approaches [86]. Also, some clinical trials have shown the cardioprotective activity of resveratrol [87].

In different animal models, doxorubicin-induced cardiotoxicity has been reported to be mitigated by the use of resveratrol [88-93]. Multiple mechanisms could be responsible for the protective effect of resveratrol especially ROS generation [94], inducing antioxidant enzymes such as SOD [90,91,95-97], catalase [90,95,97], NADPH quinine-oxidoreductase- 1 [95], and heme oxygenase- 1 .

Other mechanisms of cardiotoxicity protection include AMPK activation [98], inhibition of p70S6K-mediated autophagy [99], and activation of SIRT1 [96]. 
Resveratrol has shown high antiviral potential in both human and animal viral infections by inhibiting viral protein synthesis, viral related gene expressions, and inhibiting transcription and signaling pathways [6].

\section{Conclusions}

This review has explored the possibility of using chloroquine and hydroxychloroquine in the treatment of SARS-CoV-2, considering the present experiment using in vitro and in vivo clinical trials. We also explore resveratrol as an antiviral agent and a possible treatment option for SARS-CoV-2 infection or slows down its progress. However, some toxicity might be associated with these drugs (chloroquine and hydroxychloroquine). What we thought to be effective may later be more harmful. However, we suggest resveratrol due to its cardioprotective activities to mitigate the side effect of chloroquine and hydroxychloroquine. There is an urgent need for effective treatment against SARS-CoV-2 but the synergistic use of drugs with proven antiviral properties and could mitigate any potential side effects that could involve long term use could be explored.

\section{Funding}

This research received no external funding.

\section{Acknowledgments}

This research has no acknowledgment.

\section{Conflicts of Interest}

The authors declare no conflict of interest.

\section{References}

1. Mégarbane, B.; Scherrmann, J.-M. Hydroxychloroquine and Azithromycin to Treat Patients With COVID19: Both Friends and Foes? The Journal of Clinical Pharmacology 2020, 60, 808-814, https://doi.org/10.1002/jcph.1646.

2. Hashem, A.M.; Alghamdi, B.S.; Algaissi, A.A.; Alshehri, F.S.; Bukhari, A.; Alfaleh, M.A.; Memish, Z.A. Therapeutic use of chloroquine and hydroxychloroquine in COVID-19 and other viral infections: A narrative review. Travel Med. Infect. Dis. 2020, 35, 101735, https://doi.org/10.1016/j.tmaid.2020.101735.

3. Devaux, C.A.; Rolain, J.-M.; Colson, P.; Raoult, D. New insights on the antiviral effects of chloroquine against coronavirus: what to expect for COVID-19? Int. J. Antimicrob. Agents 2020, 55, 105938, https://doi.org/10.1016/j.ijantimicag.2020.105938.

4. Liu, J.; Cao, R.; Xu, M.; Wang, X.; Zhang, H.; Hu, H.; Li, Y.; Hu, Z.; Zhong, W.; Wang, M. Hydroxychloroquine, a less toxic derivative of chloroquine, is effective in inhibiting SARS-CoV-2 infection in vitro. Cell Discovery 2020, 6, 16, https://doi.org/10.1038/s41421-020-0156-0.

5. Campagna, M.; Rivas, C. Antiviral activity of resveratrol. Biochem. Society Trans., 2010, 381, 50-53, https://doi.org/10.1042/BST0380050

6. Filardo, S.; Di Pietro, M.; Mastromarino, P.; Sessa, R. Therapeutic potential of resveratrol against emerging respiratory viral infections. Pharmacol. Ther. 2020, 214, 107613, https://doi.org/10.1016/j.pharmthera.2020.107613.

7. Pastick, K.A.; Okafor, E.C.; Wang, F.; Lofgren, S.M.; Skipper, C.P.; Nicol, M.R.; Pullen, M.F.; Rajasingham, R.; McDonald, E.G.; Lee, T.C.; Schwartz, I.S.; Kelly, L.E.; Lother, S.A.; Mitjà, O.; Letang, E.; Abassi, M.; Boulware, D.R. Review: Hydroxychloroquine and Chloroquine for Treatment of SARSCoV-2 (COVID-19). Open Forum Infectious Diseases 2020, 7, https://doi.org/10.1093/ofid/ofaa130.

8. Singh, A.K.; Singh, A.; Shaikh, A.; Singh, R.; Misra, A. Chloroquine and hydroxychloroquine in the treatment of COVID-19 with or without diabetes: A systematic search and a narrative review with a special reference to India and other developing countries. Diabetes \& Metabolic Syndrome: Clinical Research \& Reviews 2020, 14, 241-246, https://doi.org/10.1016/j.dsx.2020.03.011. 
9. Sanders, J.M.; Monogue, M.L.; Jodlowski, T.Z.; Cutrell, J.B. Pharmacologic Treatments for Coronavirus Disease 2019 (COVID-19): A Review. JAMA 2020, 323, 1824-1836, https://doi.org/10.1001/jama.2020.6019.

10. Gautret, P.; Lagier, J.-C.; Parola, P.; Hoang, V.T.; Meddeb, L.; Mailhe, M.; Doudier, B.; Courjon, J.; Giordanengo, V.; Vieira, V.E.; Tissot Dupont, H.; Honoré, S.; Colson, P.; Chabrière, E.; La Scola, B.; Rolain, J.-M.; Brouqui, P.; Raoult, D. Hydroxychloroquine and azithromycin as a treatment of COVID-19: results of an open-label non-randomized clinical trial. Int. J. Antimicrob. Agents 2020, 56, 105949; https://doi.org/10.1016/j.ijantimicag.2020.105949.

11. Kwiek, J.J.; Haystead, T.A.J.; Rudolph, J. Kinetic Mechanism of Quinone Oxidoreductase 2 and Its Inhibition by the Antimalarial Quinolines. Biochemistry 2004, 43, 4538-4547, https://doi.org/10.1021/bi035923w.

12. Vincent, M.J.; Bergeron, E.; Benjannet, S.; Erickson, B.R.; Rollin, P.E.; Ksiazek, T.G.; Seidah, N.G.; Nichol, S.T. Chloroquine is a potent inhibitor of SARS coronavirus infection and spread. Virol J. 2005, 2, 69, https://doi.org/10.1186/1743-422X-2-69.

13. Hoffmann, M.; Kleine-Weber, H.; Schroeder, S.; Krüger, N.; Herrler, T.; Erichsen, S.; Schiergens, T.S.; Herrler, G.; Wu, N.-H.; Nitsche, A. SARS-CoV-2 cell entry depends on ACE2 and TMPRSS2 and is blocked by a clinically proven protease inhibitor. Cell 2020, https://doi.org/10.1016/j.cell.2020.02.052.

14. Zhou, W.; Wang, H.; Yang, Y.; Chen, Z.-S.; Zou, C.; Zhang, J. Chloroquine against malaria, cancers and viral diseases. Drug Discov. Today 2020, 25, 2012-2022, https://doi.org/10.1016/j.drudis.2020.09.010.

15. Khan, M.; Santhosh, S.R.; Tiwari, M.; Lakshmana Rao, P.V.; Parida, M. Assessment of in vitro prophylactic and therapeutic efficacy of chloroquine against Chikungunya virus in vero cells. J. Med. Virol. 2010, 82, 817-824, https://doi.org/10.1002/jmv.21663.

16. Carew, J.S.; Espitia, C.M.; Esquivel, J.A.; Mahalingam, D.; Kelly, K.R.; Reddy, G.; Giles, F.J.; Nawrocki, S.T. Lucanthone is a novel inhibitor of autophagy that induces cathepsin D-mediated apoptosis. J. Biol. Chem. 2011, 286, 6602-6613, https://doi.org/10.1074/jbc.M110.151324.

17. Savarino, A. Use of chloroquine in viral diseases. The Lancet Infectious Diseases 2011, 11, 653-654, https://doi.org/10.1016/S1473-3099(11)70092-5.

18. Encouse, B.G.; Hee-Yeon, C.; Florence, M.H.; Stan, G.L.; Axel, H.S.; Thomas, C.C. Quinoline-based antimalarial drugs: a novel class of autophagy inhibitors. Neurosurgical Focus FOC 2015, 38, E12, https://doi.org/10.3171/2014.12.FOCUS14748.

19. Randolph, V.B.; Winkler, G.; Stollar, V. Acidotropic amines inhibit proteolytic processing of flavivirus prM protein. Virology 1990, 174, 450-458, https://doi.org/10.1016/0042-6822(90)90099-D.

20. Savarino, A.; Di Trani, L.; Donatelli, I.; Cauda, R.; Cassone, A. New insights into the antiviral effects of chloroquine. The Lancet Infectious Diseases 2006, 6, 67-69, https://doi.org/10.1016/S1473-3099(06)703619.

21. Lotteau, V.; Teyton, L.; Peleraux, A.; Nilsson, T.; Karlsson, L.; Schmid, S.L.; Quaranta, V.; Peterson, P.A. Intracellular transport of class II MHC molecules directed by invariant chain. Nature 1990, 348, 600-605, https://doi.org/10.1038/348600a0.

22. Wu, S.-F.; Chang, C.-B.; Hsu, J.-M.; Lu, M.-C.; Lai, N.-S.; Li, C.; Tung, C.-H. Hydroxychloroquine inhibits CD154 expression in CD4+ T lymphocytes of systemic lupus erythematosus through NFAT, but not STAT5, signaling. Arthrit. Res. Ther. 2017, 19, 183, https://doi.org/10.1186/s13075-017-1393-y.

23. Wang, M.; Cao, R.; Zhang, L.; Yang, X.; Liu, J.; Xu, M.; Shi, Z.; Hu, Z.; Zhong, W.; Xiao, G. Remdesivir and chloroquine effectively inhibit the recently emerged novel coronavirus (2019-nCoV) in vitro. Cell Res. 2020, 30, 269-271, https://doi.org/10.1038/s41422-020-0282-0.

24. Yao, X.; Ye, F.; Zhang, M.; Cui, C.; Huang, B.; Niu, P.; Liu, X.; Zhao, L.; Dong, E.; Song, C.; Zhan, S.; Lu, R.; Li, H.; Tan, W.; Liu, D. In Vitro Antiviral Activity and Projection of Optimized Dosing Design of Hydroxychloroquine for the Treatment of Severe Acute Respiratory Syndrome Coronavirus 2 (SARS-CoV2). Clin. Infect. Dis. 2020, 71, 732-739, https://doi.org/10.1093/cid/ciaa237.

25. Keyaerts, E.; Li, S.; Vijgen, L.; Rysman, E.; Verbeeck, J.; Van Ranst, M.; Maes, P. Antiviral Activity of Chloroquine against Human Coronavirus OC43 Infection in Newborn Mice. Antimicrob. Agents Chemother. 2009, 53, 3416, https://doi.org/10.1128/AAC.01509-08.

26. Niu, J.; Shen, L.; Huang, B.; Ye, F.; Zhao, L.; Wang, H.; Deng, Y.; Tan, W. Non-invasive bioluminescence imaging of HCoV-OC43 infection and therapy in the central nervous system of live mice. Antiviral Res. 2020, 173, 104646, https://doi.org/10.1016/j.antiviral.2019.104646.

27. Barnard, D.L.; Day, C.W.; Bailey, K.; Heiner, M.; Montgomery, R.; Lauridsen, L.; Chan, P.K.S.; Sidwell, R.W. Evaluation of immunomodulators, interferons and known in vitro SARS-coV inhibitors for inhibition of SARS-coV replication in BALB/c mice. Antiviral Chem. Chemother. 2006, 17, 275-284, https://doi.org/10.1177/095632020601700505.

28. Takano, T.; Katoh, Y.; Doki, T.; Hohdatsu, T. Effect of chloroquine on feline infectious peritonitis virus infection in vitro and in vivo. Antiviral Res. 2013, 99, 100-107, https://doi.org/10.1016/j.antiviral.2013.04.016. 
29. Chen, Z.; Hu, J.; Zhang, Z.; Jiang, S.; Han, S.; Yan, D.; Zhuang, R.; Hu, B.; Zhang, Z. Efficacy of hydroxychloroquine in patients with COVID-19: results of a randomized clinical trial. medRxiv 2020; https://doi.org/10.1101/2020.03.22.20040758.

30. Chen, J.; Liu, D.; Liu, L.; Liu, P.; Xu, Q.; Xia, L.; Ling, Y.; Huang, D.; Song, S.; Zhang, D. A pilot study of hydroxychloroquine in treatment of patients with moderate COVID-19. Zhejiang da xиe xиe bao. Yi xиe ban= Journal of Zhejiang University. Medical sciences 2020, 49 https://doi.org/10.3785/j.issn.10089292.2020.03.03.

31. Molina, J.M.; Delaugerre, C.; Le Goff, J.; Mela-Lima, B.; Ponscarme, D.; Goldwirt, L.; de Castro, N. No evidence of rapid antiviral clearance or clinical benefit with the combination of hydroxychloroquine and azithromycin in patients with severe COVID-19 infection. Med. Mal. Infect. 2020, 50, 384, https://doi.org/10.1016/j.medmal.2020.03.006.

32. Magagnoli, J.; Narendran, S.; Pereira, F.; Cummings, T.H.; Hardin, J.W.; Sutton, S.S.; Ambati, J. Outcomes of hydroxychloroquine usage in United States veterans hospitalized with Covid-19. Med 2020, https://doi.org/10.1016/j.medj.2020.06.001.

33. Mahevas, M.; Tran, V.-T.; Roumier, M.; Chabrol, A.; Paule, R.; Guillaud, C.; Gallien, S.; Lepeule, R.; Szwebel, T.-A.; Lescure, X.; Schlemmer, F.; Matignon, M.; Khellaf, M.; Crickx, E.; Terrier, B.; Morbieu, C.; Legendre, P.; Dang, J.; Schoindre, Y.; Pawlotski, J.-M.; Michel, M.; Perrodeau, E.; Carlier, N.; Roche, N.; De Lastours, V.; Mouthon, L.; Audureau, E.; Ravaud, P.; Godeau, B.; Costedoat, N. No evidence of clinical efficacy of hydroxychloroquine in patients hospitalized for COVID-19 infection with oxygen requirement: results of a study using routinely collected data to emulate a target trial. medRxiv 2020, https://doi.org/10.1101/2020.04.10.20060699.

34. Million, M.; Gautret, P.; Colson, P.; Roussel, Y.; Dubourg, G.; Chabriere, E.; Honore, S.; Rolain, J.M.; Fenollar, F.; Fournier, P.E.; Lagier, J.C.; Parola, P.; Brouqui, P.; Raoult, D. Clinical efficacy of chloroquine derivatives in COVID-19 infection: comparative meta-analysis between the big data and the real world. New Microbes and New Infections 2020, 38, 100709, https://doi.org/10.1016/j.nmni.2020.100709.

35. Barbosa, J.; Kaitis, D.; Freedman, R.; Le, K.; Lin, X. Clinical outcomes of hydroxychloroquine in hospitalized patients with COVID-19: a quasi-randomized comparative study. N. Engl. J. Med. 2020.

36. Tang, W.; Cao, Z.; Han, M.; Wang, Z.; Chen, J.; Sun, W.; Wu, Y.; Xiao, W.; Liu, S.; Chen, E.; Chen, W.; Wang, X.; Yang, J.; Lin, J.; Zhao, Q.; Yan, Y.; Xie, Z.; Li, D.; Yang, Y.; Liu, L.; Qu, J.; Ning, G.; Shi, G.; Xie, Q. Hydroxychloroquine in patients with mainly mild to moderate coronavirus disease 2019: open label, randomised controlled trial. BMJ 2020, 369, m1849, https://doi.org/10.1136/bmj.m1849.

37. Borba, M.G.S.; Val, F.F.A.; Sampaio, V.S.; Alexandre, M.A.A.; Melo, G.C.; Brito, M.; Mourão, M.P.G.; Brito-Sousa, J.D.; Baía-da-Silva, D.; Guerra, M.V.F.; Hajjar, L.A.; Pinto, R.C.; Balieiro, A.A.S.; Pacheco, A.G.F.; Santos, J.D.O., Jr.; Naveca, F.G.; Xavier, M.S.; Siqueira, A.M.; Schwarzbold, A.; Croda, J.; Nogueira, M.L.; Romero, G.A.S.; Bassat, Q.; Fontes, C.J.; Albuquerque, B.C.; Daniel-Ribeiro, C.-T.; Monteiro, W.M.; Lacerda, M.V.G.; for the CloroCovid, T. Effect of High vs Low Doses of Chloroquine Diphosphate as Adjunctive Therapy for Patients Hospitalized With Severe Acute Respiratory Syndrome Coronavirus 2 (SARS-CoV-2) Infection: A Randomized Clinical Trial. JAMA Network Open 2020, 3, e208857-e208857, https://doi.org/10.1001/jamanetworkopen.2020.8857.

38. Chorin, E.; Dai, M.; Shulman, E.; Wadhwani, L.; Roi Bar, C.; Barbhaiya, C.; Aizer, A.; Holmes, D.; Bernstein, S.; Spinelli, M.; Park, D.S.; Chinitz, L.A.; Jankelson, L. The QT Interval in Patients with SARSCoV-2 Infection Treated with Hydroxychloroquine/Azithromycin. medRxiv 2020, https://doi.org/10.1101/2020.04.02.20047050.

39. Gao, J.; Tian, Z.; Yang, X. Breakthrough: Chloroquine phosphate has shown apparent efficacy in treatment of COVID-19 associated pneumonia in clinical studies. Biosci. Trends 2020, 14, 72-73, https://doi.org/10.5582/bst.2020.01047.

40. Keyaerts, E.; Vijgen, L.; Maes, P.; Neyts, J.; Ranst, M.V. In vitro inhibition of severe acute respiratory syndrome coronavirus by chloroquine. Biochem. Biophys. Res. Commun. 2004, 323, 264-268, https://doi.org/10.1016/j.bbrc.2004.08.085.

41. Costedoat-Chalumeau, N.; Hulot, J.S.; Amoura, Z.; Leroux, G.; Lechat, P.; Funck-Brentano, C.; Piette, J.C. Heart conduction disorders related to antimalarials toxicity: an analysis of electrocardiograms in 85 patients treated with hydroxychloroquine for connective tissue diseases. Rheumatology 2007, 46, 808-810, https://doi.org/10.1093/rheumatology/kel402.

42. Mason, J.W. Antimicrobials and QT prolongation. J. Antimicrob. Chemother. 2017, 72, 1272-1274, https://doi.org/10.1093/jac/dkw591.

43. Chatre, C.; Roubille, F.; Vernhet, H.; Jorgensen, C.; Pers, Y.-M. Cardiac Complications Attributed to Chloroquine and Hydroxychloroquine: A Systematic Review of the Literature. Drug Saf. 2018, 41, 919-931, https://doi.org/10.1007/s40264-018-0689-4.

44. Geng, Y.; Kohli, L.; Klocke, B.J.; Roth, K.A. Chloroquine-induced autophagic vacuole accumulation and cell death in glioma cells is p53 independent. Neuro Oncol. 2010, 12, 473-481, https://doi.org/10.1093/neuonc/nop048. 
45. Mauthe, M.; Orhon, I.; Rocchi, C.; Zhou, X.; Luhr, M.; Hijlkema, K.-J.; Coppes, R.P.; Engedal, N.; Mari, M.; Reggiori, F. Chloroquine inhibits autophagic flux by decreasing autophagosome-lysosome fusion. Autophagy 2018, 14, 1435-1455, https://doi.org/10.1080/15548627.2018.1474314.

46. Traebert, M.; Dumotier, B.; Meister, L.; Hoffmann, P.; Dominguez-Estevez, M.; Suter, W. Inhibition of hERG K+ currents by antimalarial drugs in stably transfected HEK293 cells. Eur. J. Pharmacol. 2004, 484, 41-48, https://doi.org/10.1016/j.ejphar.2003.11.003.

47. Noujaim, S.F.; Stuckey, J.A.; Ponce-Balbuena, D.; Ferrer-Villada, T.; López-Izquierdo, A.; Pandit, S.V.; Sánchez-Chapula, J.A.; Jalife, J. Structural bases for the different anti-fibrillatory effects of chloroquine and quinidine. Cardiovasc. Res. 2011, 89, 862-869, https://doi.org/10.1093/cvr/cvr008.

48. Munster, T.; Gibbs, J.P.; Shen, D.; Baethge, B.A.; Botstein, G.R.; Caldwell, J.; Dietz, F.; Ettlinger, R.; Golden, H.E.; Lindsley, H.; McLaughlin, G.E.; Moreland, L.W.; Roberts, W.N.; Rooney, T.W.; Rothschild, B.; Sack, M.; Sebba, A.I.; Weisman, M.; Welch, K.E.; Yocum, D.; Furst, D.E. Hydroxychloroquine concentration-response relationships in patients with rheumatoid arthritis. Arthritis Rheum. 2002, 46, 14601469, https://doi.org/10.1002/art.10307.

49. Yam, J.C.S.; Kwok, A.K.H. Ocular toxicity of hydroxychloroquine. Hong Kong Medical Journal 2006, 12, 294.

50. Michaelides, M.; Stover, N.B.; Francis, P.J.; Weleber, R.G. Retinal Toxicity Associated With Hydroxychloroquine and Chloroquine: Risk Factors, Screening, and Progression Despite Cessation of Therapy. Arch. Ophthalmol. 2011, 129, 30-39, https://doi.org/10.1001/archophthalmol.2010.321.

51. Liu, D.; Li, X.; Zhang, Y.; Kwong, J.S.-W.; Li, L.; Zhang, Y.; Xu, C.; Li, Q.; Sun, X.; Tian, H. Chloroquine and hydroxychloroquine are associated with reduced cardiovascular risk: a systematic review and metaanalysis. Drug Des. Devel. Ther. 2018, 12, 1685, https://doi.org/10.2147/DDDT.S166893.

52. Balamurugesan, K.; Davis, P.; Ponprabha, R.; Sarasveni, M. Chloroquine induced urticaria: A newer adverse effect. Journal of Family Medicine and Primary Care 2019, 8, 2545-2547, https://doi.org/10.4103/jfmpc.jfmpc_413_19.

53. Seçkin, Ü.; Özoran, K.; Ikinciogullari, A.; Borman, P.; Bostan, E.E. Hydroxychloroquine ototoxicity in a patient with rheumatoid arthritis. Rheumatol. Int. 2000, 19, 203-204, https://doi.org/10.1007/s002960000054.

54. Sciarretta, S.; Hariharan, N.; Monden, Y.; Zablocki, D.; Sadoshima, J. Is Autophagy in Response to Ischemia and Reperfusion Protective or Detrimental for the Heart? Pediatr. Cardiol. 2011, 32, 275-281, https://doi.org/10.1007/s00246-010-9855-X.

55. Ma, X.; Liu, H.; Foyil Sarah, R.; Godar Rebecca, J.; Weinheimer Carla, J.; Hill Joseph, A.; Diwan, A. Impaired Autophagosome Clearance Contributes to Cardiomyocyte Death in Ischemia/Reperfusion Injury. Circulation 2012, 125, 3170-3181, https://doi.org/10.1161/CIRCULATIONAHA.111.041814.

56. Sciarretta, S.; Maejima, Y.; Zablocki, D.; Sadoshima, J. The Role of Autophagy in the Heart. Annu. Rev. Physiol. 2018, 80, 1-26, https://doi.org/10.1146/annurev-physiol-021317-121427.

57. Bourke, L.; McCormick, J.; Taylor, V.; Pericleous, C.; Blanchet, B.; Costedoat-Chalumeau, N.; Stuckey, D.; Lythgoe, M.F.; Stephanou, A.; Ioannou, Y. Hydroxychloroquine Protects against Cardiac Ischaemia/Reperfusion Injury In Vivo via Enhancement of ERK1/2 Phosphorylation. PLoS One 2015, 10, e0143771, https://doi.org/10.1371/journal.pone.0143771.

58. Macdonald, R.D.; Engel, A.G. Experimental Chloroquine Myopathy*†. J. Neuropathol. Exp. Neurol. 1970, 29, 479-499, https://doi.org/10.1097/00005072-197007000-00010.

59. Kamp Timothy, J.; Hamdan Mohamed, H.; January Craig, T. Chloroquine or Hydroxychloroquine for COVID-19: Is Cardiotoxicity a Concern? Journal of the American Heart Association 2020, 9, e016887, https://doi.org/10.1161/JAHA.120.016887.

60. Zupančič, Š.; Lavrič, Z.; Kristl, J. Stability and solubility of trans-resveratrol are strongly influenced by $\mathrm{pH}$ and temperature. Eur. J. Pharm. Biopharm. 2015, 93, 196-204, https://doi.org/10.1016/j.ejpb.2015.04.002.

61. Walle, T.; Hsieh, F.; DeLegge, M.H.; Oatis, J.E.; Walle, U.K. High Absorption But Very Low Bioavailability Of Oral Resveratrol In Humans. Drug Metab. Disposition 2004, 32, 1377, https://doi.org/10.1124/dmd.104.000885.

62. Shaito, A.; Posadino, A.M.; Younes, N.; Hasan, H.; Halabi, S.; Alhababi, D.; Al-Mohannadi, A.; AbdelRahman, W.M.; Eid, A.H.; Nasrallah, G.K. Potential adverse effects of resveratrol: a literature review. Int. J. Mol. Sci. 2020, 21, 2084, https://doi.org/10.3390/ijms21062084.

63. Vestergaard, M.; Ingmer, H. Antibacterial and antifungal properties of resveratrol. Int. J. Antimicrob. Agents 2019, 53, 716-723, https://doi.org/10.1016/j.ijantimicag.2019.02.015.

64. Di Pietro, M.; Filardo, S.; Falasca, F.; Turriziani, O.; Sessa, R. Infectious agents in atherosclerotic cardiovascular diseases through oxidative stress. Int. J. Mol. Sci. 2017, 18, 2459, https://doi.org/10.3390/ijms18112459.

65. Xia, N.; Daiber, A.; Förstermann, U.; Li, H. Antioxidant effects of resveratrol in the cardiovascular system. Br. J. Pharmacol. 2017, 174, 1633-1646, https://doi.org/10.1111/bph.13492.

66. Pannu, N.; Bhatnagar, A. Resveratrol: from enhanced biosynthesis and bioavailability to multitargeting chronic diseases. Biomed. Pharmacother. 2019, 109, 2237-2251, https://doi.org/10.1016/j.biopha.2018.11.075. 
67. Tomé-Carneiro, J.; Larrosa, M.; Yáñez-Gascón, M.J.; Dávalos, A.; Gil-Zamorano, J.; Gonzálvez, M.; García-Almagro, F.J.; Ruiz Ros, J.A.; Tomás-Barberán, F.A.; Espín, J.C.; García-Conesa, M.-T. One-year supplementation with a grape extract containing resveratrol modulates inflammatory-related microRNAs and cytokines expression in peripheral blood mononuclear cells of type 2 diabetes and hypertensive patients with coronary artery disease. Pharmacol. Res. 2013, 72, 69-82, https://doi.org/10.1016/j.phrs.2013.03.011.

68. Cheng, C.K.; Luo, J.-Y.; Lau, C.W.; Chen, Z.-Y.; Tian, X.Y.; Huang, Y. Pharmacological basis and new insights of resveratrol action in the cardiovascular system. Br. J. Pharmacol. 2020, 177, 1258-1277, https://doi.org/10.1111/bph.14801.

69. Cottart, C.-H.; Nivet-Antoine, V.; Laguillier-Morizot, C.; Beaudeux, J.-L. Resveratrol bioavailability and toxicity in humans. Mol. Nutr. Food Res. 2010, 54, 7-16, https://doi.org/10.1002/mnfr.200900437.

70. Meng, X.; Zhou, J.; Zhao, C.-N.; Gan, R.-Y.; Li, H.-B. Health Benefits and Molecular Mechanisms of Resveratrol: A Narrative Review. Foods 2020, 9, 340, https://doi.org/10.3390/foods9030340.

71. Schwager, J.; Richard, N.; Widmer, F.; Raederstorff, D. Resveratrol distinctively modulates the inflammatory profiles of immune and endothelial cells. BMC Complement. Altern. Med. 2017, 17, 309, https://doi.org/10.1186/s12906-017-1823-z.

72. Misawa, T.; Saitoh, T.; Kozaki, T.; Park, S.; Takahama, M.; Akira, S. Resveratrol inhibits the acetylated $\alpha-$ tubulin-mediated assembly of the NLRP3-inflammasome. Int. Immunol. 2015, 27, 425-434, https://doi.org/10.1093/intimm/dxv018.

73. Berretta, M.; Bignucolo, A.; Di Francia, R.; Comello, F.; Facchini, G.; Ceccarelli, M.; Iaffaioli, R.V.; Quagliariello, V.; Maurea, N. Resveratrol in Cancer Patients: From Bench to Bedside. Int. J. Mol. Sci. 2020, 21, 2945, https://doi.org/10.3390/ijms21082945.

74. Euba, B.; López-López, N.; Rodríguez-Arce, I.; Fernández-Calvet, A.; Barberán, M.; Caturla, N.; Martí, S.; Díez-Martínez, R.; Garmendia, J. Resveratrol therapeutics combines both antimicrobial and immunomodulatory properties against respiratory infection by nontypeable Haemophilus influenzae. Sci. Rep. 2017, 7, 12860, https://doi.org/10.1038/s41598-017-13034-7.

75. Yin, Y.; Wunderink, R.G. MERS, SARS and other coronaviruses as causes of pneumonia. Respirology 2018, 23, 130-137, https://doi.org/10.1111/resp.13196.

76. Lai, C.-C.; Shih, T.-P.; Ko, W.-C.; Tang, H.-J.; Hsueh, P.-R. Severe acute respiratory syndrome coronavirus 2 (SARS-CoV-2) and coronavirus disease-2019 (COVID-19): The epidemic and the challenges. Int. J. Antimicrob. Agents 2020, 55, 105924, https://doi.org/10.1016/j.ijantimicag.2020.105924.

77. Zhao, X.; Tong, W.; Song, X.; Jia, R.; Li, L.; Zou, Y.; He, C.; Liang, X.; Lv, C.; Jing, B.; Lin, J.; Yin, L.; Ye, G.; Yue, G.; Wang, Y.; Yin, Z. Antiviral Effect of Resveratrol in Piglets Infected with Virulent Pseudorabies Virus. Viruses 2018, 10, 457, https://doi.org/10.3390/v10090457.

78. Lin, S.-C.; Ho, C.-T.; Chuo, W.-H.; Li, S.; Wang, T.T.; Lin, C.-C. Effective inhibition of MERS-CoV infection by resveratrol. BMC Infect. Dis. 2017, 17, 144, https://doi.org/10.1186/s12879-017-2253-8.

79. Zhao, X.; Xu, J.; Song, X.; Jia, R.; Yin, Z.; Cheng, A.; Jia, R.; Zou, Y.; Li, L.; Yin, L.; Yue, G.; Lv, C.; Jing, B. Antiviral effect of resveratrol in ducklings infected with virulent duck enteritis virus. Antiviral Res. 2016, 130, 93-100, https://doi.org/10.1016/j.antiviral.2016.03.014.

80. Zhao, X.; Cui, Q.; Fu, Q.; Song, X.; Jia, R.; Yang, Y.; Zou, Y.; Li, L.; He, C.; Liang, X.; Yin, L.; Lin, J.; Ye, G.; Shu, G.; Zhao, L.; Shi, F.; Lv, C.; Yin, Z. Antiviral properties of resveratrol against pseudorabies virus are associated with the inhibition of IкB kinase activation. Sci. Rep. 2017, 7, 8782, https://doi.org/10.1038/s41598-017-09365-0.

81. Abba, Y.; Hassim, H.; Hamzah, H.; Noordin, M.M. Antiviral activity of resveratrol against human and animal viruses. Adv. Virol. 2015, 2015, https://doi.org/10.1155/2015/184241.

82. Baldassarre, M.E.; Di Mauro, A.; Labellarte, G.; Pignatelli, M.; Fanelli, M.; Schiavi, E.; Mastromarino, P.; Capozza, M.; Panza, R.; Laforgia, N. Resveratrol plus carboxymethyl- $\beta$-glucan in infants with common cold: A randomized double-blind trial. Heliyon 2020, e03814, https://doi.org/10.1016/j.heliyon.2020.e03814.

83. Böhm, M.; Rosenkranz, S.; Laufs, U. Alcohol and red wine: impact on cardiovascular risk. Nephrology Dialysis Transplantation 2004, 19, 11-16, https://doi.org/10.1093/ndt/gfg340.

84. Lin, J.-F.; Lin, S.-M.; Chih, C.-L.; Nien, M.-W.; Su, H.-H.; Hu, B.-R.; Huang, S.-S.; Tsai, S.-K. Resveratrol reduces infarct size and improves ventricular function after myocardial ischemia in rats. Life Sci. 2008, 83, 313-317, https://doi.org/10.1016/j.lfs.2008.06.016.

85. Palomer, X.; Capdevila-Busquets, E.; Álvarez-Guardia, D.; Barroso, E.; Pallàs, M.; Camins, A.; Davidson, M.M.; Planavila, A.; Villarroya, F.; Vázquez-Carrera, M. Resveratrol induces nuclear factor- $\kappa$ B activity in human cardiac cells. Int. J. Cardiol. 2013, 167, 2507-2516, https://doi.org/10.1016/j.ijcard.2012.06.006.

86. de Oliveira, J.C.; Antonietto, C.R.K.; Scalabrini, A.C.; Marinho, T.S.; Pernomian, L.; Corrêa, J.W.N.; Restini, C.B.A. Antioxidant protective effects of the resveratrol on the cardiac and vascular tissues from renal hypertensive rats. 2012, https://doi.org/10.4236/ojmc.2012.23008.

87. Xia, N.; Strand, S.; Schlufter, F.; Siuda, D.; Reifenberg, G.; Kleinert, H.; Förstermann, U.; Li, H. Role of SIRT1 and FOXO factors in eNOS transcriptional activation by resveratrol. Nitric Oxide 2013, 32, 29-35, https://doi.org/10.1016/j.niox.2013.04.001. 
88. Rezk, Y.A.; Balulad, S.S.; Keller, R.S.; Bennett, J.A. Use of resveratrol to improve the effectiveness of cisplatin and doxorubicin: study in human gynecologic cancer cell lines and in rodent heart. Am. J. Obstet. Gynecol. 2006, 194, e23-e26, https://doi.org/10.1016/j.ajog.2005.11.030.

89. Wang, G.Y.; Wang, Y.M.; Zhang, L.N.; Li, Q.; Yue, H.; Song, C.M.; Feng, J.K.; Wang, N. Effect of resveratrol on heart function of rats with adriamycin-induced heart failure. Zhongguo Zhong yao za zhi= Zhongguo zhongyao zazhi= China journal of Chinese materia medica 2007, 32, 1563-1565.

90. Tatlidede, E.; Şehirli, Ö.; Velioğlu-Öğünç, A.; Çetinel, Ş.; Yeğen, B.Ç.; Yarat, A.; Süleymanoğlu, S.; Şener, G. Resveratrol treatment protects against doxorubicin-induced cardiotoxicity by alleviating oxidative damage. Free Radical Res. 2009, 43, 195-205, https://doi.org/10.1080/10715760802673008.

91. Dolinsky, V.W.; Rogan, K.J.; Sung, M.M.; Zordoky, B.N.; Haykowsky, M.J.; Young, M.E.; Jones, L.W.; Dyck, J.R.B. Both aerobic exercise and resveratrol supplementation attenuate doxorubicin-induced cardiac injury in mice. American Journal of Physiology-Endocrinology and Metabolism 2013, 305, E243-E253, https://doi.org/10.1152/ajpendo.00044.2013.

92. Osman, A.-M.M.; Al-Harthi, S.E.; AlArabi, O.M.; Elshal, M.F.; Ramadan, W.S.; Alaama, M.N.; AlKreathy, H.M.; Damanhouri, Z.A.; Osman, O.H. Chemosensetizing and cardioprotective effects of resveratrol in doxorubicin- treated animals. Cancer Cell Int. 2013, 13, 52, https://doi.org/10.1186/14752867-13-52.

93. Arafa, M.H.; Mohammad, N.S.; Atteia, H.H.; Abd-Elaziz, H.R. Protective effect of resveratrol against doxorubicin-induced cardiac toxicity and fibrosis in male experimental rats. J. Physiol. Biochem. 2014, 70, 701-711, https://doi.org/10.1007/s13105-014-0339-y.

94. Salazar-Mendiguchía, J.; González-Costello, J.; Roca, J.; Ariza-Solé, A.; Manito, N.; Cequier, Á. Anthracycline-mediated cardiomyopathy: basic molecular knowledge for the cardiologist. Arch Cardiol. Mex. 2014, 84, 218-223, http://dx.doi.org/10.1016/j.acmx.2013.08.006.

95. Cao, Z.; Li, Y. Potent induction of cellular antioxidants and phase 2 enzymes by resveratrol in cardiomyocytes: protection against oxidative and electrophilic injury. Eur. J. Pharmacol. 2004, 489, 39-48, https://doi.org/10.1016/j.ejphar.2004.02.031.

96. Brookins Danz, E.D.; Skramsted, J.; Henry, N.; Bennett, J.A.; Keller, R.S. Resveratrol prevents doxorubicin cardiotoxicity through mitochondrial stabilization and the Sirt1 pathway. Free Radical Biol. Med. 2009, 46, 1589-1597, https://doi.org/10.1016/j.freeradbiomed.2009.03.011. c

97. Wang, J.; He, D.; Zhang, Q.; Han, Y.; Jin, S.; Qi, F. Resveratrol Protects Against Cisplatin-Induced Cardiotoxicity by Alleviating Oxidative Damage. Cancer Biother. Radiopharm. 2009, 24, 675-680, https://doi.org/10.1089/cbr.2009.0679.

98. Gu, J.; Song, Z.-p.; Gui, D.-m.; Hu, W.; Chen, Y.-g.; Zhang, D.-d. Resveratrol Attenuates DoxorubicinInduced Cardiomyocyte Apoptosis in Lymphoma Nude Mice by Heme Oxygenase-1 Induction. Cardiovasc. Toxicol. 2012, 12, 341-349, https://doi.org/10.1007/s12012-012-9178-7.

99. Xu, X.; Chen, K.; Kobayashi, S.; Timm, D.; Liang, Q. Resveratrol Attenuates Doxorubicin-Induced Cardiomyocyte Death via Inhibition of p70 S6 Kinase 1-Mediated Autophagy. J. Pharmacol. Exp. Ther. 2012, 341, 183, https://doi.org/10.1124/jpet.111.189589. 